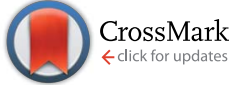

Cite this: RSC Adv., 2017, 7, 7631

\title{
Hydroxyapatite synthesis from a starfish and $\beta$ - tricalcium phosphate using a hydrothermal method
}

Received 16th November 2016 Accepted 19th December 2016

DOI: $10.1039 / c 6 r a 26907 a$

www.rsc.org/advances

\author{
V. Rodríguez-Lugo, ${ }^{\text {*a }}$ E. Salinas-Rodríguez, ${ }^{a}$ R. A. Vázquez, ${ }^{a}$ K. Alemán ${ }^{b}$ \\ and A. L. Rivera*c
}

Hydroxyapatite $\mathrm{HAp}, \mathrm{Ca}_{10}\left(\mathrm{PO}_{4}\right)_{6}(\mathrm{OH})_{2}$, was successfully synthesized using a hydrothermal method using $\beta$ tricalcium phosphate ( $\beta$-TCP) and $\mathrm{CaO}$ from the starfish Mellita eduardobarrosoi sp. nov. The goal of this research was to synthesize a material with better characteristics, such as a high proportion of the HAp phase, homogeneous dimensions, and a good Ca/P ratio. To get it, different temperatures, concentration ratios and reaction times were tested. Synthesized HAp materials were characterized by Scanning Electron Microscopy (SEM), X-ray powder diffraction (XRD), and Fourier transform infrared spectroscopy (FTIR). XRD showed that the proportion of the HAp phase tends to increase as the temperature and reaction times grow, which is corroborated by SEM characterization, where homogeneous in size HAp fibers were identified. Absorption bands related to the functional groups $\mathrm{PO}_{4}$ and $\mathrm{OH}$, as well as the characteristics of HAp, were found by FTIR. From the results obtained, optimal HAp is achieved at a temperature of $250{ }^{\circ} \mathrm{C}$ and a reaction time of 48 hours, producing a greater proportion of fibers with very homogeneous lengths and thicknesses, a Ca/P ratio of 1.65 (near stoichiometric), a higher crystalline degree, and a ratio of $3: 1$ of $\beta-\mathrm{TCP}$ and $\mathrm{CaO}$.

\section{Introduction}

Recently, for biomedical applications, there have been numerous efforts to find materials with suitable characteristics for the restoration or replacement of bone tissue in humans, ${ }^{1}$ and to develop new technologies that can improve the properties of these materials. Amongst the most popular materials for this goal is hydroxyapatite (HAp), the principal inorganic compound of hard tissues (bones and teeth), ${ }^{2}$ due to its crystalline nature, chemical composition similar to natural bones, structure, biocompatibility, ability to establish chemical exchange and form interfacial bonds with living tissue, thus promoting integration processes and the growth of new bone, its antimicrobial character ${ }^{3}$ (that can be used for the treatment of dental caries ${ }^{4}$ ), and osteo-conduction properties. ${ }^{5}$ HAp promotes the direct generation of new bones without the use of intervening fibrous tissue; this method is widely accepted in maxillofacial surgery to fill bone defects created by cysts or tumors, traumas, congenital diseases, and other surgeries. ${ }^{6-9}$

${ }^{a}$ Universidad Autónoma del Estado de Hidalgo, Área Académica de Ciencias de la Tierra y Materiales, Carretera Pachuca-Tulancingo Km. 4.5, C.P. 42184, Pachuca, Hidalgo, Mexico.E-mail: ventura.rl65@gmail.com

${ }^{b}$ Universidad Autónoma del Estado de Hidalgo, Área Académica de Computación y Electrónica, Carretera Pachuca-Tulancingo Km. 4.5, C.P. 42184, Pachuca, Hidalgo, Mexico

'Instituto de Ciencias Nucleares, Centro de Ciencias de la Complejidad, Universidad Nacional Autónoma de México, Apartado Postal 70-543, Deleg. Coyoacán, Mexico City, C.P. 04510, Mexico. E-mail: anarivera2000@gmail.com
HAp doped with magnetic ions have also been used as an efficient drug deliver for the treatment of tumors and damage cells. ${ }^{\mathbf{1 0 - 1 2}}$ For clinical applications, due to its high biocompatibility, HAp represents the best alternative as a biomaterial in reconstructive surgery, because it can be used successfully as a filler material. ${ }^{13-23}$ Moreover, due to its high porosity, it is widely used as a catalytic agent. ${ }^{24}$

The term "apatite" is applied to a large group of mineral compounds featuring a general formula: ${ }^{9} \mathrm{~A}_{10}\left(\mathrm{BP}_{4}\right)_{6} \mathrm{X}_{2}$, where $\mathrm{A}$ can be $\mathrm{Ca}, \mathrm{Sr}, \mathrm{Ba}, \mathrm{Cd}$, or other rare earth elements; $\mathrm{BP}_{4}$ can be $\mathrm{PO}_{4}{ }^{3-}, \mathrm{VO}_{4}{ }^{3-}, \mathrm{SiO}_{4}{ }^{3-}$, or $\mathrm{AsO}_{4}{ }^{3-}$; and $\mathrm{X}$ can take the form of $\mathrm{OH}^{-}, \mathrm{Cl}^{-}$, or $\mathrm{F}^{-}$. HAp is a type of apatite ${ }^{9}$ and its chemical formula is $\mathrm{Ca}_{10}\left(\mathrm{PO}_{4}\right)_{6}(\mathrm{OH})_{2}$, where $39 \%$ of its weight is $\mathrm{Ca}$, $5.18 \%$ is $\mathrm{P}$, and $3.38 \%$ is $\mathrm{OH}$. HAp crystallizes in a hexagonal system with a space group of $P 6_{3} / m$ type; the dimensions of the unit cell are $a=b=9.432 \AA$, $c=6.881 \AA .{ }^{25}$ The stoichiometric $\mathrm{Ca} / \mathrm{P}$ ratio of HAp is 1.666 and its density is $3.219 \mathrm{~g} \mathrm{~cm}^{-3}$. The structure of HAp consists of an array of tetrahedral phosphates $\left(\mathrm{PO}_{4}{ }^{3}\right)$ constituting the "backbone" of the unit cell; $2 \mathrm{O}_{2}$ molecules are aligned with axis $C$, and the other 2 are in a horizontal plane. ${ }^{25-27}$ Within the unit cell, phosphates are divided into two layers of $1 / 4$ and $3 / 4$ heights, which favor the formation of two types of channels along axis $\mathrm{C}$, referred to as type A and type $\mathrm{B}$, respectively. ${ }^{28}$

HAp can be synthesized by various techniques using different reactants and production routes, that can modify its physicochemical properties, morphology, chemical composition homogeneity, particle sizes, and degree of crystallinity. ${ }^{5}$ 
Daubrée, in 1851, was the first who synthesized HAp by passing phosphorus trichloride vapor on red hot lime. ${ }^{29-32}$ Since then, various methods of synthesis have been employed: ${ }^{33-37}$ solid state synthesis, synthesis in aqueous phase, ${ }^{38}$ growth from molten salts, growth in gel, hydrolysis, mechano-chemical, and the hydrothermal method. In the development of this work was employed the hydrothermal technique because it promotes the growth of various crystals, is cheap and simple to implement. In this method, water is used as a solvent at higher energies to accelerate synthesis and to achieve a better balance of the reaction; this means that products with high crystallinity are obtained, and the corrosion and degradation processes are accelerated. ${ }^{39}$ These features facilitate the growth of fine crystals, which are homogenous in size, shape, and composition. The growing interest in the hydrothermal technique is derived from its numerous advantages, including the high reactivity of the reactants, easy control of the solution, formation of both the meta-stable phases and the unique phases, less air pollution in the reaction, and low power consumption. ${ }^{\mathbf{4 0}}$

On Mexican beaches a source of environmental pollution are shells from corals, cockle, and in particular from starfish. These shells due to its high content on $\mathrm{CaCO}_{3}$ can be used as a potential source of the calcium required to produce HAp. ${ }^{\text {11-47 }}$ Thus, employing starfish as precursor of HAp, not only generates an important biomaterial, but also provides a solution to deal with this ecological waste.

In this work, HAp synthesis is done by a hydrothermal method using $\beta$-tricalcium phosphate $(\beta$-TCP) and $\mathrm{CaO}(\mathrm{ob}-$ tained from the decomposition of $\mathrm{CaCO}_{3}$ of the starfish of the species "Mellita eduardobarrosoi sp. nov."). Different working conditions were tested, a ratio of $3: 1$; for temperatures of $230{ }^{\circ} \mathrm{C}$ and $250{ }^{\circ} \mathrm{C}$; and reaction times of 20 and 48 hours. The characterization of the precursors and the obtained products was done through Low Vacuum Scanning Electron Microscopy (LV-SEM), elemental chemical analysis (EDS), X-ray diffraction (XRD), and Fourier transform infrared spectroscopy (FTIR); which allowed the identification of crystalline phases, morphology, chemical composition, and molecular arrangements. Using a waste product, low cost, short term reactions, close to room temperatures, simplicity of the method and good quality of the HAp produced are some of the advantages of the methodology used in this work, that can be implemented for HAp synthesis at industrial scale.

\section{Experimental procedure}

\section{Materials used and synthesis systems}

To carry out the synthesis of HAp, $\beta$-TCP reagent grade Fluka and remnants of the echinoidea starfish Mellita eduardobarroso $i$ sp. nov. were used. This starfish has compositional and structural properties that make it good as precursor for biomaterials. $^{\mathbf{4 0 , 4 8 , 4 9}}$ The starfish was collected on the beaches of the northern region of Veracruz state, Mexico. It consists mainly of $\mathrm{CaCO}_{3}$. Regarding the starfish, this was subjected to a prior cleaning process that consisted of placing the samples for in a $30 \%$ hypochlorite solution for 7 days to remove organic material both externally and internally; the samples were subsequently dried and placed in an ultrasound system for periods of 10 minutes to remove any sand deposits that may have been within the starfish (see Fig. 1). The synthesis process used in this study to obtain HAp was the hydrothermal method, for which an autoclave "Cortest Hastolly" was used with a capacity of $250 \mathrm{~mL}$. This system can reach a maximum temperature of $300{ }^{\circ} \mathrm{C}$ and a pressure of $5.51 \mathrm{MPa}$.

\section{Hydrothermal synthesis method}

The hydrothermal method was used for the synthesis process. Starfish were subject to treatment at $900{ }^{\circ} \mathrm{C}$ for 20 and 48 hours, which led to the formation of calcium oxide ( $\mathrm{CaO})$, according to the reaction given by:

$$
\mathrm{CaCO}_{3} \stackrel{\Delta}{\longrightarrow} \mathrm{CaO}+\mathrm{CO}_{2} \uparrow
$$

The synthesis process involves mixing in $100 \mathrm{~mL}$ of deionized water; $4.5 \mathrm{~g}$ of $\beta$-TCP, and $0.28 \mathrm{~g}$ of $\mathrm{CaO}$ of the starfish, which was heat treated. Following this, there was a wait time for the chemical reaction to be effected, which is represented by:

$$
\mathrm{CaO}+3\left(\mathrm{Ca}_{3}\left(\mathrm{PO}_{4}\right)_{2}\right)+\mathrm{H}_{2} \mathrm{O} \stackrel{\Delta}{\longrightarrow} \mathrm{Ca}_{10}\left(\mathrm{PO}_{4}\right)_{6}(\mathrm{OH})_{2}
$$

The mixture that was obtained was treated under hydrothermal conditions in an autoclave "Cortest Hastolly", the conditions are shown in Table 1 . Here is reported the synthesis made through the hydrothermal method during $20 \mathrm{~h}$ and $48 \mathrm{~h}$. The morphology definition and fiber density is larger for longer reaction times as was shown in previous published papers. ${ }^{17,18,50-53}$

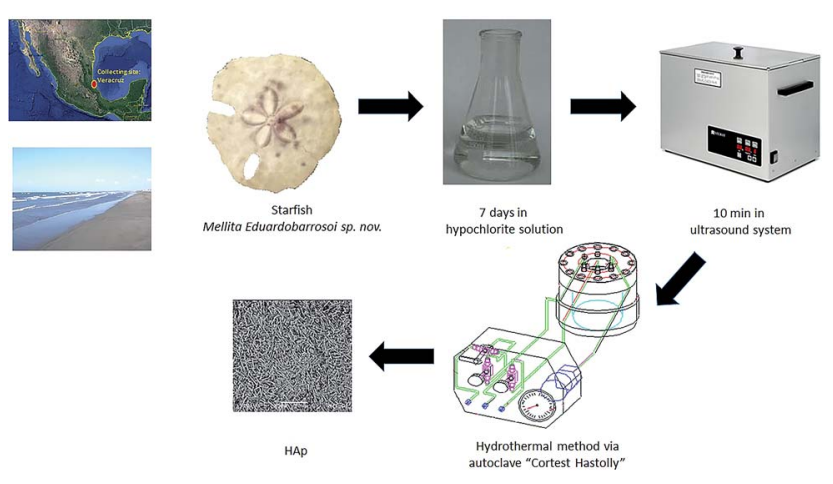

Fig. 1 Experimental procedure for HAp synthesis.

Table 1 Employed synthesis conditions conducted under hydrothermal process

\begin{tabular}{llll}
\hline $\begin{array}{l}\text { Synthesis } \\
\text { number }\end{array}$ & $\begin{array}{l}\text { Temperature } \\
\left({ }^{\circ} \mathrm{C}\right)\end{array}$ & $\begin{array}{l}\text { Pressure } \\
(\mathrm{MPa})\end{array}$ & $\begin{array}{l}\text { Reaction } \\
\text { time (hours) }\end{array}$ \\
\hline 1 & 230 & 3.4 & 20 \\
2 & 250 & 3.4 & 20 \\
3 & 230 & 3.4 & 48 \\
4 & 250 & 3.4 & 48
\end{tabular}




\section{Characterization techniques}

For the microstructural characterization process, X-ray diffraction (XRD), low vacuum scanning electron microscopy (LV-SEM), and spectrometry by Fourier transform infrared (FTIR) were used, employing the following equipment:

(a) X-ray diffractometer, XRD, for powders (SIEMENS, model D-5000) with an incident beam wavelength of $\lambda_{\mathrm{Cu}}=1.5405 \AA$. Said system was adapted with the JCPDS-ICOD database (International Center of Diffraction Data) version 2.16, which was used for phase identification. The working conditions were as follows: $35 \mathrm{kV} ; 25 \mathrm{~mA}$; with a sweep carried out in the range of $2.5^{\circ}$ to $70^{\circ}$ in $2 \theta$ with a time of $1 \mathrm{~s}$ and an increment of 0.005 . The different samples were ground in an agate mortar and they were then placed in respective supports to finally be placed in the diffractometer.

(b) LV-SEM (JEOL model JMS 5900-LV) equipped with a probe for elemental chemical analysis, EDS (OXFORD brand). The operating conditions were as follows: a low vacuum mode; an accelerating voltage of $25 \mathrm{kV}$; a $75 \mathrm{~mA}$ emission current; a working distance (WD) of $10 \mathrm{~mm}$; a pressure of $20 \mathrm{~Pa}$; and a spot size of 40$50 \mathrm{~mm}$. On a $10 \mathrm{~mm}$ diameter aluminum cylinder, a carbon ribbon was adhered and the test sample was placed in it.

(c) Fourier transform infrared spectrometer (Fourier transform model NEXUS 670 FT-IR ESP, Niclet brand). Each test sample was previously dried at a temperature of $100{ }^{\circ} \mathrm{C}$ for 24 hours. Following this, each sample was mixed with potassium bromide (KBr) for final placement in the spectrometer's chamber.

\section{Results}

The precursors and the products obtained following the synthesis of HAp using the hydrothermal method for different conditions were characterized by LV-SEM, EDS, XRD, and FTIR spectrometry.

\section{Characterization of precursors: starfish}

Echinoids like the starfish Mellita eduardobarrosoi sp. nov. have a skeleton composed of calcite $\left(\mathrm{CaCO}_{3}\right)$, a material of low density and hardness that is comparable to high density limestone. ${ }^{48}$ This starfish is from the genus of the mellitidae, clypeasteroidea order and equine class of the phylium echinoidermata. In their adult age they have sizes between 10 and $150 \mathrm{~mm}$, their outline is irregular, but has vertical symmetry, the ventral surface is flat and the dorsal surface is thickened, usually presents 5 elongated perforations, its coloration varies from beige, gold and gold-ocher with shades of green (see Fig. 2a). Surface morphology of the starfish is shown in Fig. $2 \mathrm{~b}$ where it can be seen predominant circular pores with diameters between $6.25 \mu \mathrm{m}$ and $25 \mu \mathrm{m}$. When making a transverse cut in the starfish for analysis, it was observed that the pores are interconnected, as shown in Fig. 2c. The internal pores have dimensions on average ranging from $10 \mu \mathrm{m}$ to $22.5 \mu \mathrm{m}$. Elemental chemical analysis (EDS) of the starfish identify as the main chemical elements that comprise it: $\mathrm{O}, \mathrm{C}, \mathrm{Ca}$. Low proportions or $\mathrm{Mg}, \mathrm{Al}, \mathrm{Si}$, and $\mathrm{S}$ were also detected (see Table 2).

After the grinding process, the morphology of the starfish powder changes, the porous structure has totally disappeared,

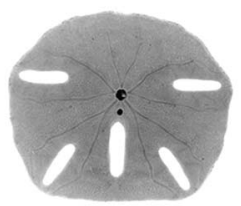

(b)

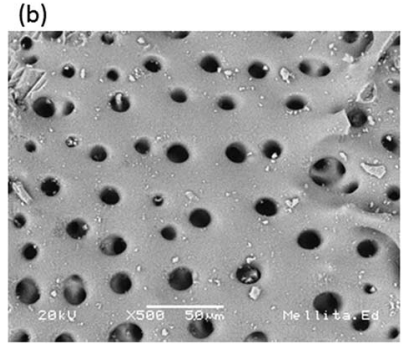

Fig. 2 Starfish Mellita eduardobarrosoi sp. nov. (a) bottom and top superficial view, (b) superficial morphology, and (c) internal structure.

Table 2 Elemental chemical analysis of the starfish

\begin{tabular}{lll}
\hline Element & $\begin{array}{l}\text { Starfish without } \\
\text { treatment }\end{array}$ & $\begin{array}{l}\text { Starfish after thermal } \\
\text { treatment at } 900{ }^{\circ} \mathrm{C} \text { for } 4 \mathrm{~h}\end{array}$ \\
\hline $\mathrm{O}$ & 46.50 & 26.05 \\
$\mathrm{C}$ & 25.98 & 3.01 \\
$\mathrm{Ca}$ & 24.48 & 65.34 \\
$\mathrm{Mg}$ & 1.93 & 2.37 \\
$\mathrm{Al}$ & 0.47 & - \\
$\mathrm{Si}$ & 0.36 & - \\
$\mathrm{S}$ & 0.21 & -
\end{tabular}

with particles ranging from $2.5 \mu \mathrm{m}$ to $22.5 \mu \mathrm{m}$ (see LV-SEM image, left panel of Fig. 3). Starfish powder after the grinding and cleaning process was also characterized by XRD (upper panel of Fig. 4). Magnesium calcite $(\mathrm{CaMg}) \mathrm{CO}_{3}$ is the only phase identified. FTIR spectrum is shown in the bottom of Fig. 4. It can be identified the characteristic peaks of calcite phase localized at $1800 \mathrm{~cm}^{-1}, 1422 \mathrm{~cm}^{-1}, 1084 \mathrm{~cm}^{-1}, 876 \mathrm{~cm}^{-1}$, and $710 \mathrm{~cm}^{-1}$.

\section{Characterization of the starfish after the thermal treatment}

After the thermal treatment of $900{ }^{\circ} \mathrm{C}$ during 4 hours, the resulting product of the starfish changes its morphology, appearing irregular shapes of different dimensions (see LV-SEM image, right panel of Fig. 3). EDS identify $\mathrm{Ca}$ and $\mathrm{O}$ as main elements, while $\mathrm{C}$
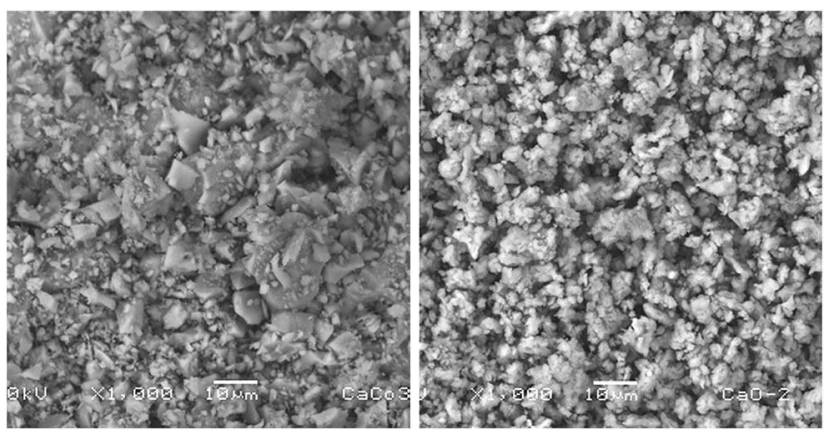

Fig. 3 LV-SEM image of the starfish after the grinding process (left panel) and after the thermal treatment (right panel). 

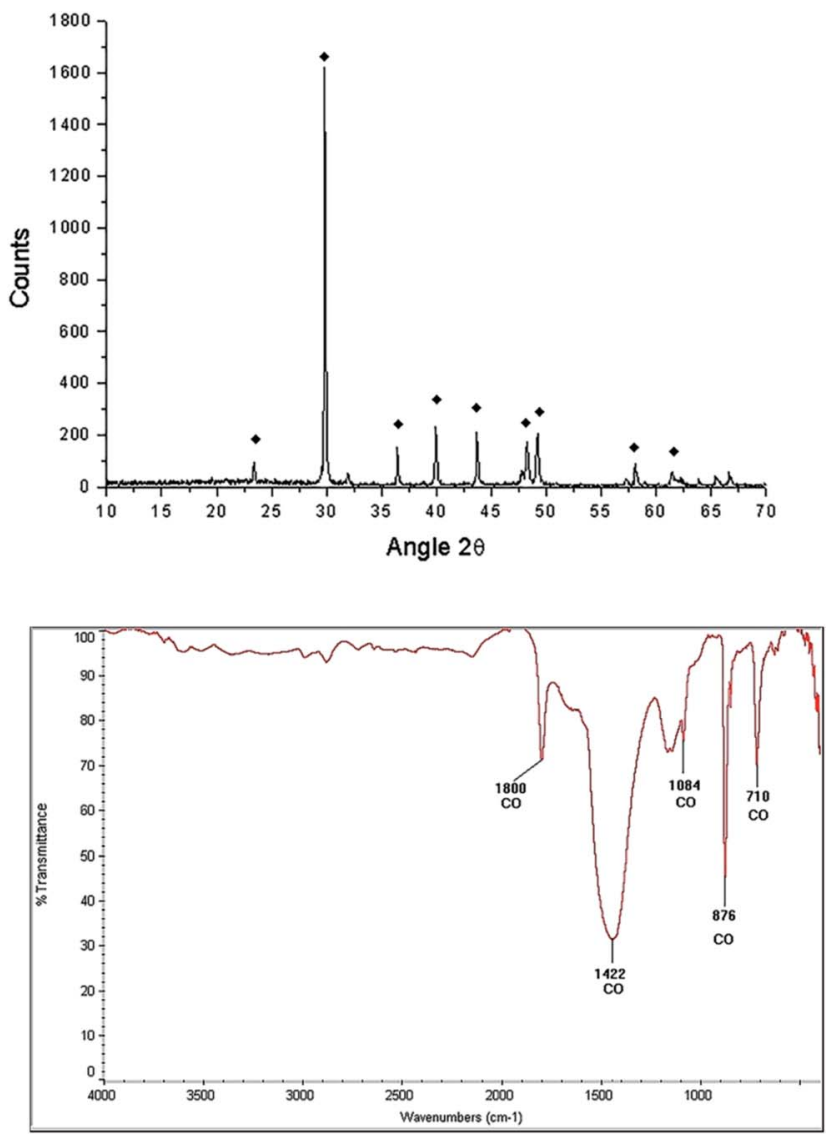

Fig. 4 Characterization of the starfish Mellita eduardobarrosoi sp. nov.: diffractogram (upper panel), black marks represent the predominant phase which corresponds to magnesium calcite, and FTIR spectrogram (lower panel).

and $\mathrm{Mg}$ appear in smaller proportions, whereas $\mathrm{Al}$ and $\mathrm{Si}$ are not detected (see Table 2). When comparing the identified chemical elements of the starfish prior to the thermal treatment, calcium percentage increase, as well as the decrease of carbon, magnesium, and oxygen is notable (Table 2).

Starfish product after the thermal treatment was also characterized by XRD (Fig. 5 upper panel). Three phases can be appreciated: calcium oxide [CaO], magnesium oxide [MgO], and portlandite $\left[\mathrm{Ca}(\mathrm{OH})_{2}\right]$. The latter could be formed after the treatment when it comes into contact with the ambient humidity according to the following chemical reaction:

$$
\mathrm{CaO}+\mathrm{H}_{2} \mathrm{O} \rightarrow \mathrm{Ca}(\mathrm{OH})_{2} \text {. }
$$

FTIR spectroscopy of the starfish after thermal treatment (Fig. 5 bottom panel) indicates the presence of a band at $3641 \mathrm{~cm}^{-1}$, which corresponds to a $\mathrm{O}-\mathrm{H}$ type bond, associated with the presence of the hydroxyl of the portlandite phase. The bands identified at 876 $\mathrm{cm}^{-1}, 1120 \mathrm{~cm}^{-1}, 1420 \mathrm{~cm}^{-1}$ correspond to the calcite phase.

\section{Characterization of precursors: $\beta$-TCP}

$\beta$-TCP $\left[\mathrm{Ca}_{3}\left(\mathrm{PO}_{4}\right)_{2}\right]$ is a porous calcium phosphate ceramic, ${ }^{54}$ irregular in shape, biocompatible with hard tissue, it has a molecular weight (wt) of $310.18 \mathrm{~g}$, usually is an amorphous
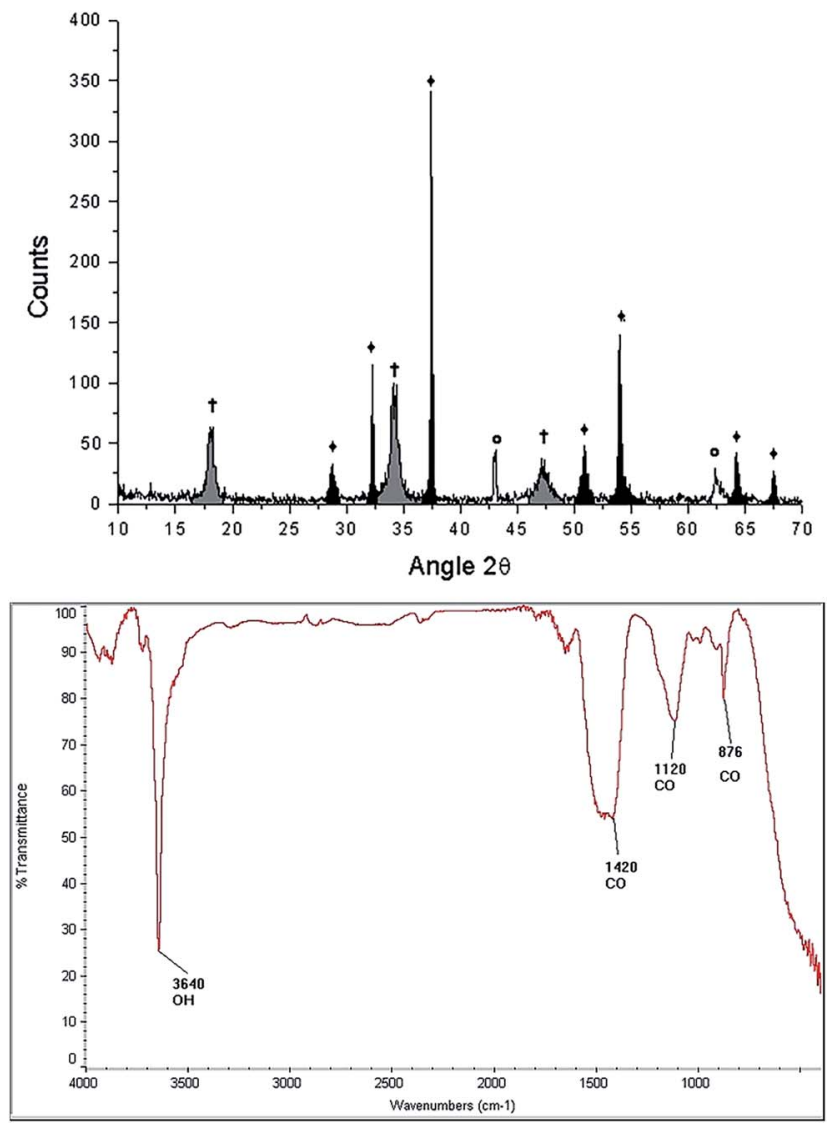

Fig. 5 Characterization of the starfish Mellita eduardobarrosoi sp. nov. after the thermal treatment: diffractogram (up) showing the phases: ${ }^{\dagger}\left[\mathrm{Ca}(\mathrm{OH})_{2}\right], \bullet[\mathrm{CaO}],{ }^{\Theta}[\mathrm{MgO}]$, and FTIR spectrogram (bottom).

powder, not soluble in water, alcohol or acetic acid and soluble in $\mathrm{HCl}$ and $\mathrm{HNO}_{3}$. The characteristic morphology of the $\beta$-TCP used in our hydrothermal synthesis is shown in Fig. 6. It can be observed that it is formed of grains, which basically have two sizes, the small ones from $1.76 \mu \mathrm{m}$ to $4.11 \mu \mathrm{m}$, while the larger ones have values of $5.3 \mu \mathrm{m}$ to $9.41 \mu \mathrm{m}$. XRD analysis only shows the $\beta$-TCP phase (Fig. 7 upper panel). FTIR spectrogram (Fig. 7 bottom panel) has bands associated to the $\mathrm{PO}_{4}$ ion, localized at $2079 \mathrm{~cm}^{-1}, 2002 \mathrm{~cm}^{-1}, 1062 \mathrm{~cm}^{-1}, 715 \mathrm{~cm}^{-1}, 605 \mathrm{~cm}^{-1}$, and 654 $\mathrm{cm}^{-1}$.

\section{Characterization of HAp obtained from the hydrothermal method using LV-SEM}

The micrograph of Fig. 8 shows the morphology associated with the product obtained by the hydrothermal method. Fig. $8 \mathrm{a}$ is the LV-SEM micrograph of the sample obtained by the hydrothermal method at $230{ }^{\circ} \mathrm{C}$ for 20 hours, in which individual grains and agglomerates with sizes ranging from $3.22 \mu \mathrm{m}$ to $3.87 \mu \mathrm{m}$ in length are observed; individual grains had dimensions ranging from $2.25 \mu \mathrm{m}$ to $2.90 \mu \mathrm{m}$. The particles exhibiting irregular morphologies are scarce, with dimensions of $1.1 \mu \mathrm{m}$ $\left(\mathrm{P}_{1}\right)$ and $14.83 \mu \mathrm{m}\left(\mathrm{P}_{2}\right)$. Structures shaped fibers have different lengths ranging from $2.80 \mu \mathrm{m}$ to $42.10 \mu \mathrm{m}$, with diameters ranging from $0.60 \mu \mathrm{m}$ to $1.60 \mu \mathrm{m}$. There was a long fiber 


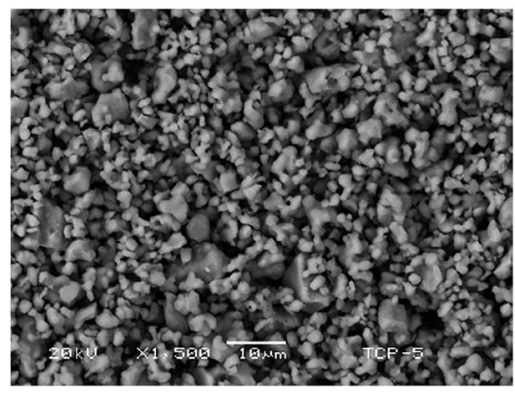

Fig. 6 LV-SEM image of the $\beta$-TCP.
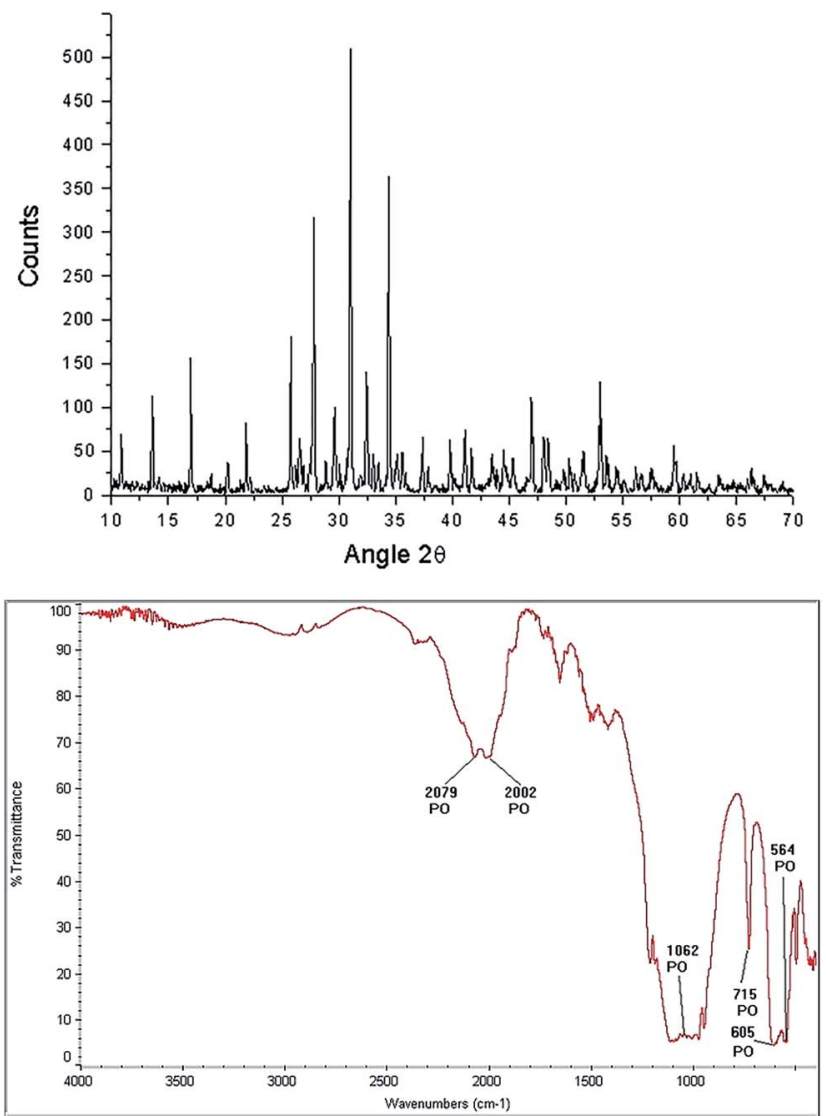

Fig. 7 Characterization of the $\beta$-TCP phase: diffractogram (up) and FTIR spectrogram (bottom).

(labeled " $F_{1}$ ") that exceed the average size with a length of 34.5 $\mu \mathrm{m}$ and a coarse fiber (denoted by " $\mathrm{F}_{2}$ ") which thickness is 2.90 $\mu \mathrm{m}$, which exceeds by far the average thickness of the other fibers. Chemical composition of the product obtained is given in Table 3, where the presence of $\mathrm{O}, \mathrm{C}, \mathrm{Ca}$, and $\mathrm{P}$ is observed with a $\mathrm{Ca} / \mathrm{P}$ ratio; in this case, it is 1.65 , which is very close to the stoichiometric ratio.

Fig. $8 \mathrm{~b}$ is the micrograph of the HAp sample obtained via hydrothermal technique at $250{ }^{\circ} \mathrm{C}$ for 20 hours. Here, it is possible to note greater homogeneity among the abundance of fiber structures. There is a tendency of forming very long fibers with sizes ranging from $36.27 \mu \mathrm{m}$ to $43.13 \mu \mathrm{m}$. Fibers of shorter

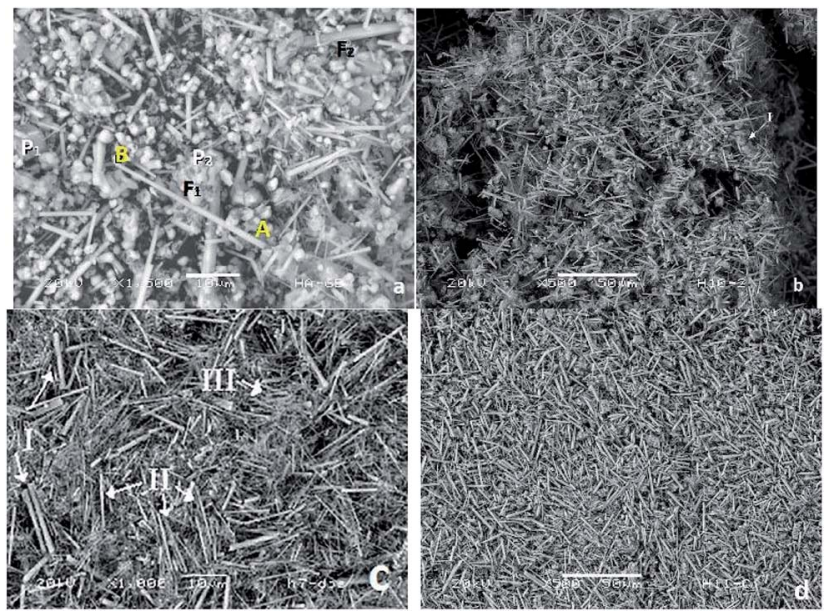

Fig. 8 LV-SEM micrographs showing the products obtained in the synthesis of HAp by hydrothermal process at (a) $230{ }^{\circ} \mathrm{C}$ for $20 \mathrm{~h}$, (b) $250{ }^{\circ} \mathrm{C}$ for $20 \mathrm{~h}$, (c) $230^{\circ} \mathrm{C}$ for $48 \mathrm{~h}$ and (d) $250{ }^{\circ} \mathrm{C}$ for $48 \mathrm{~h}$.

Table 3 Chemical composition of the synthesized product

\begin{tabular}{|c|c|c|c|c|}
\hline Sample & $\begin{array}{l}\text { Synthesis 1: } \\
230{ }^{\circ} \mathrm{C} \text { for } \\
20 \mathrm{~h}\end{array}$ & $\begin{array}{l}\text { Synthesis } 2 \text { : } \\
250{ }^{\circ} \mathrm{C} \text { for } \\
20 \mathrm{~h}\end{array}$ & $\begin{array}{l}\text { Synthesis 3: } \\
230{ }^{\circ} \mathrm{C} \text { for } \\
48 \mathrm{~h}\end{array}$ & $\begin{array}{l}\text { Synthesis } 4 \text { : } \\
250{ }^{\circ} \mathrm{C} \text { for } \\
48 \mathrm{~h}\end{array}$ \\
\hline $\mathrm{O}$ & 56.47 & $\begin{array}{l}27.92 \\
49.11\end{array}$ & 56.98 & 54.37 \\
\hline $\mathrm{Ca}$ & 21.64 & $\begin{array}{l}31.91 \\
19.94\end{array}$ & 22.21 & 20.59 \\
\hline$P$ & 13.58 & $\begin{array}{l}15.72 \\
11.57\end{array}$ & 13.39 & 12.98 \\
\hline $\mathrm{C}$ & 7.97 & $\begin{array}{l}24.44 \\
19.20\end{array}$ & 7.03 & 11.24 \\
\hline $\mathrm{Mg}$ & 0.34 & - & 0.37 & 0.27 \\
\hline $\mathrm{Ca} / \mathrm{P}$ & 1.58 & $\begin{array}{l}2.03 \\
1.72\end{array}$ & 1.66 & 1.59 \\
\hline
\end{tabular}

lengths are still identified, with diameters from $0.98 \mu \mathrm{m}$ to 1.17 $\mu \mathrm{m}$. Furthermore, there are smaller structures in the form of cluster of grains with grain sizes ranging from $1.96 \mu \mathrm{m}$ to 5.88 $\mu \mathrm{m}$. The morphologies associated with grains are illustrated in the area marked "I" in Fig. 8b, with dimensions of $15.68 \mu \mathrm{m}$. The sample is composed of $\mathrm{O}, \mathrm{Ca}, \mathrm{P}$, and $\mathrm{C}$ with minor amounts of $\mathrm{Mg}$ and a $\mathrm{Ca} / \mathrm{P}$ ratio of 1.58 (see Table 3).

In Fig. 8c, the micrograph of the sample obtained at $230{ }^{\circ} \mathrm{C}$ for 48 hours is shown. Under these conditions, it can be observed that fiber formation is favored; fibers of different dimensions, which are divided into three groups, are observed. The first group of fibers (I) have diameters of $1.29 \mu \mathrm{m}$ and average lengths ranging from $12.19 \mu \mathrm{m}$ to $14.19 \mu \mathrm{m}$, the second group of fibers (II) shows lengths ranging from $11.12 \mu \mathrm{m}$ to $16.12 \mu \mathrm{m}$ and diameters from $0.64 \mu \mathrm{m}$ to $0.96 \mu \mathrm{m}$ and, finally, in the third group (III), which is the most abundant, we can identify fibers with lengths ranging from $7.90 \mu \mathrm{m}$ to $10.12 \mu \mathrm{m}$ with an average diameter of $0.32 \mu \mathrm{m}$. In the elemental analysis presented in Table 3, it can be seen that, on average, the fibers are composed of $\mathrm{O}, \mathrm{Ca}, \mathrm{P}$, and $\mathrm{C}$; with a $\mathrm{Ca} / \mathrm{P}$ ratio of 1.59 . 
Finally, in Fig. 8d, the LV-SEM micrograph of the sample obtained via the hydrothermal method at $250{ }^{\circ} \mathrm{C}$ for 48 hours is observed. The increase in both temperature and time permit the formation of fibers with bigger dimensions (in terms of length and diameter) and with greater homogeneity. It is appreciated that the fibers correspond to the predominant morphology. They are also isolated small particles of sizes ranging from 6.86 $\mu \mathrm{m}$ to $11.76 \mu \mathrm{m}$. The fibers have lengths ranging from $41.17 \mu \mathrm{m}$ to $41.76 \mu \mathrm{m}$, diameters varying from $1.96 \mu \mathrm{m}$ to $2.15 \mu \mathrm{m}$. Samples are composed of $\mathrm{O}, \mathrm{Ca}, \mathrm{P}$, and $\mathrm{C}$, and minor amounts of $\mathrm{Mg}$, with a $\mathrm{Ca} / \mathrm{P}$ ratio of 1.65 (see Table 3).
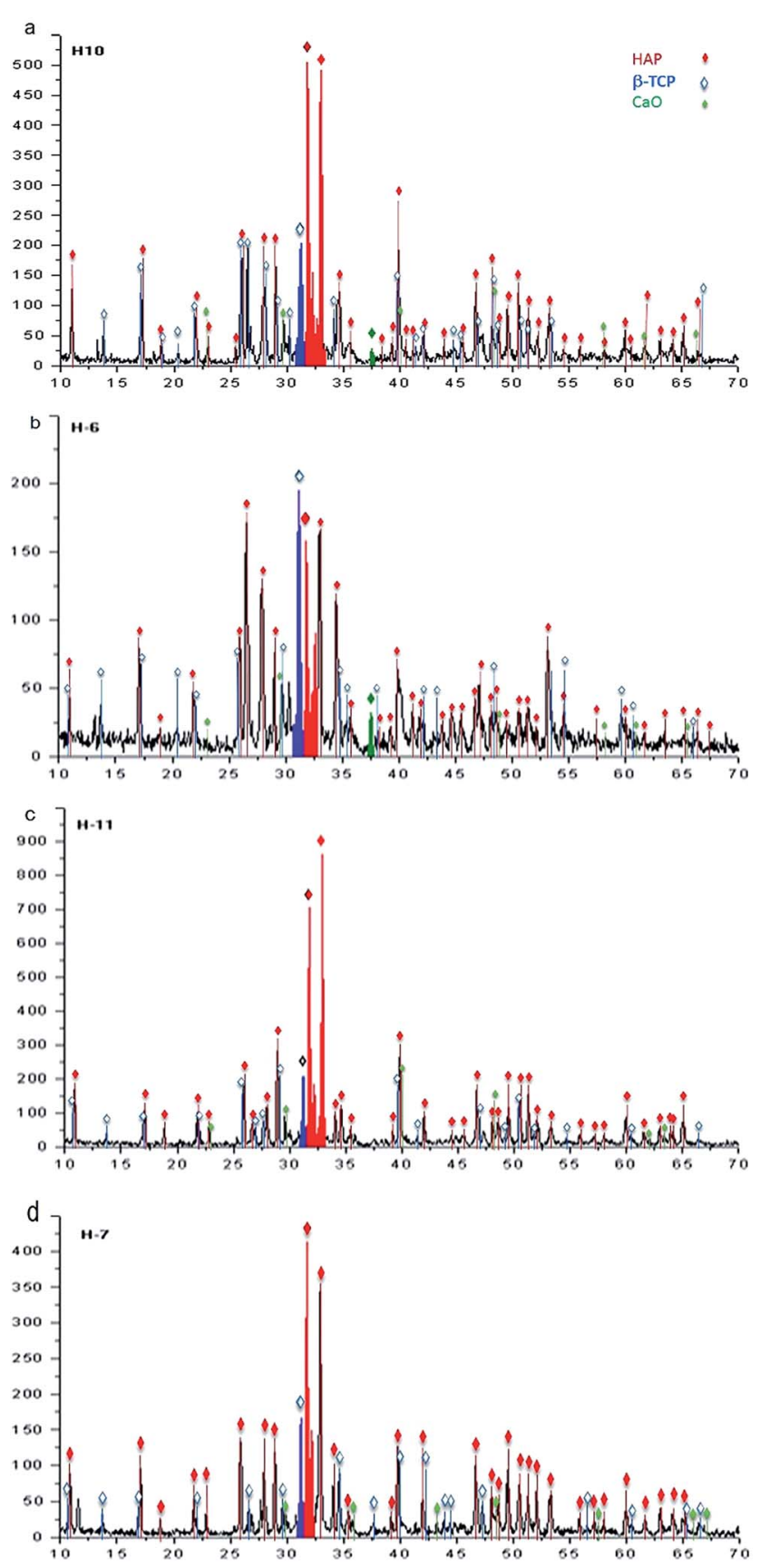

Fig. 9 X-ray spectra associated with the hydrothermal synthesis using a stoichiometric concentration ratio of $3: 1$ of $\beta-\mathrm{TCP}: \mathrm{CaO}$ for $20 \mathrm{~h}$ at (a) $230{ }^{\circ} \mathrm{C}$, (b) $250^{\circ} \mathrm{C}$, and for $48 \mathrm{~h}$ at (c) $230^{\circ} \mathrm{C}$ and (d) $250^{\circ} \mathrm{C}$.

\section{XRD characterization of HAP}

The characterization performed by XRD using a stoichiometric concentration ratio of $3: 1$ allows us to identify the presence of HAp, $\beta$-TCP, and CaO, as follows. For samples obtained at $230{ }^{\circ} \mathrm{C}$ during 20 hours, the phases of HAp, $\beta$-TCP, and $\mathrm{CaO}$ are identified, as illustrated in the diffractogram of Fig. 9a. $\beta$-TCP and $\mathrm{CaO}$ are also identified and correspond to the phases belonging precursors. In the case of samples synthesized at $250{ }^{\circ} \mathrm{C}$ during 20 hours, the results are shown in the diffractogram of Fig. 9b, in which the major diffraction peaks correspond to the phases of HAp and $\beta$-TCP. Greater definition can be observed in the case of HAp when compared with that observed for $230{ }^{\circ} \mathrm{C}$. A decrease in the intensities associated with $\beta$-TCP and $\mathrm{CaO}$ is also observed.

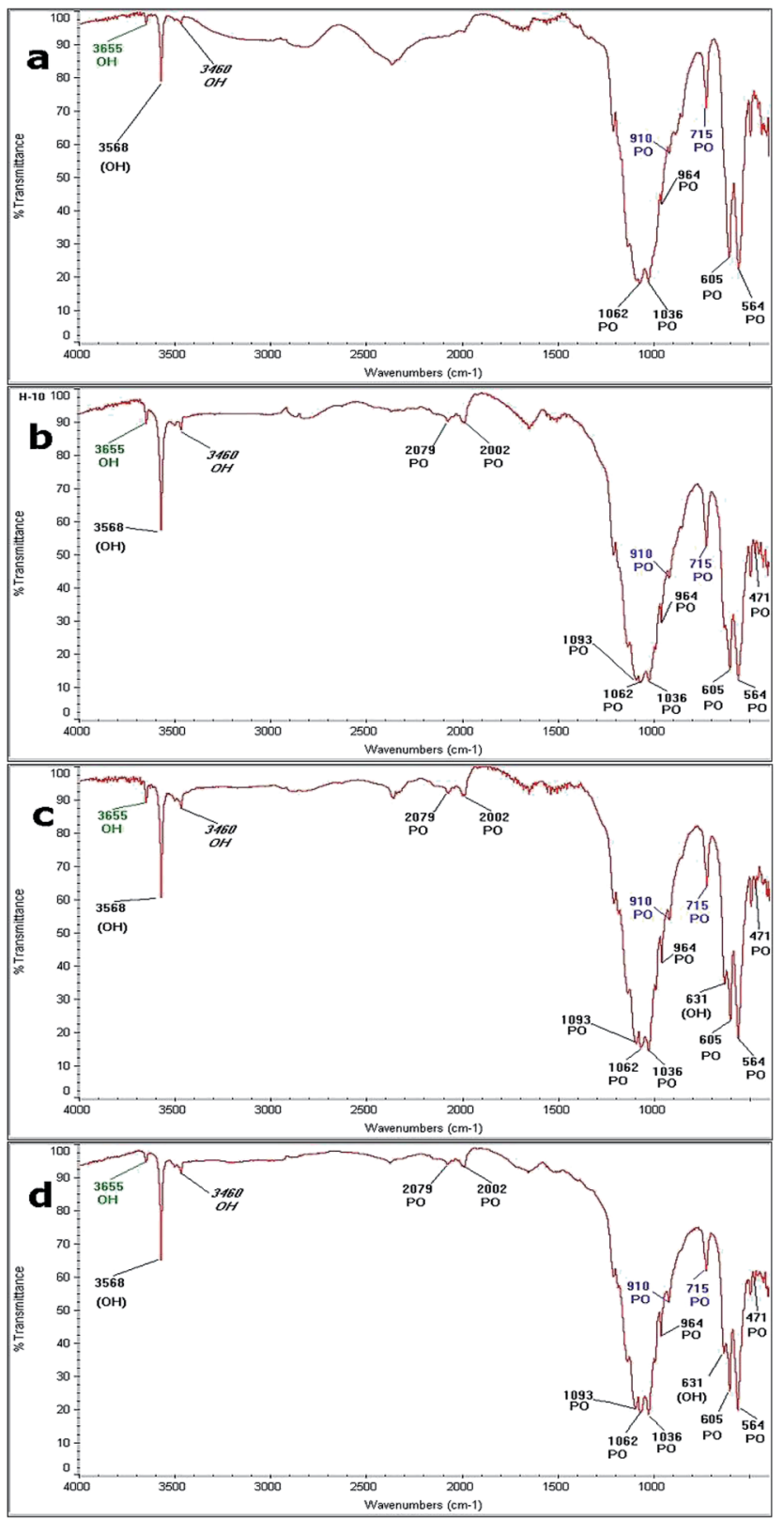

Fig. 10 FTIR spectra obtained at: (a) $230{ }^{\circ} \mathrm{C}$ for $20 \mathrm{~h}$, (b) $250{ }^{\circ} \mathrm{C}$ for $20 \mathrm{~h} \mathrm{(c)} 230{ }^{\circ} \mathrm{C}$ for $48 \mathrm{~h}$ and (d) $250{ }^{\circ} \mathrm{C}$ for $48 \mathrm{~h}$. 
Table 4 Bands (in $\mathrm{cm}^{-1}$ ) identified in the FTIR spectra for the different hydrothermal synthesis performed

\begin{tabular}{lllll}
\hline & Synthesis 1: & Synthesis 2: & Synthesis 3: & Synthesis 4: \\
& $230{ }^{\circ} \mathrm{C}$ for & $250{ }^{\circ} \mathrm{C}$ for & $230{ }^{\circ} \mathrm{C}$ for & $250{ }^{\circ} \mathrm{C}$ for \\
Bond type & $20 \mathrm{~h}$ & $20 \mathrm{~h}$ & $48 \mathrm{~h}$ & $48 \mathrm{~h}$ \\
\hline \multirow{2}{*}{ PO (HAp) } & & 2079 & 2079 & 2079 \\
& & 2002 & 2002 & 2002 \\
& 1062 & 1093 & 1093 & 1093 \\
& 1036 & 1062 & 1062 & 1062 \\
& 964 & 964 & 1036 & 1036 \\
& 605 & 605 & 964 & 964 \\
& 564 & 564 & 605 & 605 \\
& & 471 & 564 & 564 \\
OH (HAp) & 3568 & 3568 & 471 & 471 \\
& & & 3568 & 3568 \\
PO (TCP) & 910 & 910 & 631 & 631 \\
& 716 & 716 & 910 & 910 \\
OH Ca(OH) & 3655 & 3655 & 716 & 716 \\
OH humidity & 3640 & 3640 & 3655 & 3655 \\
& & & & 3640
\end{tabular}

For a reaction time of 48 hours, Fig. 9c presents the associated diffraction patterns of the sample synthesized at $230{ }^{\circ} \mathrm{C}$; these patterns are identified only as phases of $\beta$-TCP and HAp, where the latter is observed with higher intensity. In the diffractogram of Fig. 9d, the phases of $\beta$-TCP and HAp, which were identified after synthesis at a temperature of $250{ }^{\circ} \mathrm{C}$, are observed with a greater signal strength associated to the HAp phase.

\section{Characterization of HAp obtained from the hydrothermal method by FTIR spectrometry}

Fig. 10 shows the FTIR spectra obtained from the samples by hydrothermal synthesis performed at: (a) $230{ }^{\circ} \mathrm{C}$ for 20 hours; (b) $250{ }^{\circ} \mathrm{C}$ for 20 hours; (c) $230{ }^{\circ} \mathrm{C}$ for 48 hours; and (d) $250{ }^{\circ} \mathrm{C}$ for 48 hours. The bands identified in each reaction are shown in Table 4, where the bands related to the vibrational frequencies of the ions $\mathrm{PO}_{4}$ and $\mathrm{OH}$, characteristic of HAp are identified. Frequencies associated with vibrations of the $\mathrm{P}-\mathrm{O}$ bond from the $\mathrm{PO}_{4}$ ion of HAp appear at $2079 \mathrm{~cm}^{-1}, 2009$ $\mathrm{cm}^{-1}, 1093 \mathrm{~cm}^{-1}, 1062 \mathrm{~cm}^{-1}, 1036 \mathrm{~cm}^{-1}, 964 \mathrm{~cm}^{-1}, 606 \mathrm{~cm}^{-1}$, $654 \mathrm{~cm}^{-1}$, and $741 \mathrm{~cm}^{-1}$. Also, the bands associated with the O-H vibration mode characteristics of HAp at $3568 \mathrm{~cm}^{-1}$ and $631 \mathrm{~cm}^{-1}$ are observed. ${ }^{55,56}$ In the reaction performed at $230^{\circ} \mathrm{C}$ for 20 hours, five of the nine bands of the $\mathrm{PO}_{4}$ ion and one corresponding to the $\mathrm{OH}$ ion were initially observed. In all the spectra, it was possible to identify the bands related to the $\mathrm{OH}$ and $\mathrm{PO}_{4}$ ions, which are associated with the precursors ( $\beta$-TCP and $\mathrm{CaO}$ ). The bands located at $910 \mathrm{~cm}^{-1}$ and $715 \mathrm{~cm}^{-1}$ correspond to the $\mathrm{P}-\mathrm{O}$ vibration mode of the $\mathrm{PO}_{4}$ ion, which is associated with $\beta$-TCP. Furthermore, the formation of a band localized at $3650 \mathrm{~cm}^{-1}$, which may be due to the $\mathrm{OH}$ vibration mode by the presence of a hydroxyl, indicates that the formation of $\mathrm{Ca}(\mathrm{OH})_{2}$. Finally, across all spectra, it is possible to identify a band due to the $\mathrm{H}-\mathrm{O}-\mathrm{H}$ mode, which corresponds to moisture located at $3460 \mathrm{~cm}^{-1}$.

\section{Discussion}

In the present work, formation of the HAp phase via a hydrothermal method was achieved. As seen through the evaluation of all the materials parameters, the characteristics of the synthesized HAp products are associated with the precursors used, the method of synthesis employed, and the reaction conditions.

XRD analysis served to identify the effect of temperature and reaction time on the synthesized HAp. The proportion of the HAp phase tends to increase as the temperature and reaction times growth. This is corroborated by LV-SEM characterization, where HAp homogeneous fibers were identified with a $\mathrm{Ca} / \mathrm{P}$ ratio close to the stoichiometric when the reaction is carried out at high temperatures and longer reaction times.

Analysis performed by FTIR spectroscopy allowed the identification of absorption bands related to the functional groups of $\mathrm{PO}_{4}$ and $\mathrm{OH}$, as well as the characteristics of HAp and its precursors employed during synthesis, which also validates the results obtained by XRD.

From the set of results obtained in this research, it can be established that the best synthesis conditions for HAp are a temperature of $250{ }^{\circ} \mathrm{C}$ during a reaction time of 48 hours. These parameters yielded the best characteristics of HAp, including a more uniform size, greater amounts, homogeneity with a $\mathrm{Ca} / \mathrm{P}$ ratio near stoichiometric, a higher crystalline degree, and a greater fiber proportion resulting in a ratio of $3: 1$ of $\beta$-TCP and $\mathrm{CaO}$. By forming a large proportion of fibers with very homogeneous lengths and thickness, it was also possible to achieve a $\mathrm{Ca} / \mathrm{P}$ ratio of 1.65 .

Previous works ${ }^{49}$ used the same starfish Mellita eduardobarrosoi sp. nov., but the monetite $\left(\mathrm{CaHPO}_{4}\right)$ as a source of $\mathrm{PO}_{4}{ }^{3-}$. There the synthesis is carried out at longer reaction times, generating a low density of fibers with diameters from 1.1 $\mu \mathrm{m}$ to $3.3 \mu \mathrm{m}$, and $36.1 \mu \mathrm{m}$ long, and a $\mathrm{Ca} / \mathrm{P}$ ratio of 1.24 to 1.50 . As in the present method, were obtained portlandite products $\left[\mathrm{Ca}(\mathrm{OH})_{2}\right]$, calcium oxide $[\mathrm{CaO}]$ and magnesium oxide $[\mathrm{MgO}]{ }^{49}$ In contrast, when $\beta$-TCP is used (as in this paper) longer reaction times (250 hours) promote the formation of a higher density of fibers having sizes ranging from $2.80 \mu \mathrm{m}$ to $42.10 \mu \mathrm{m}$ in length and of diameter from $0.60 \mu \mathrm{m}$ to $1.60 \mu \mathrm{m}$, with a $\mathrm{Ca} / \mathrm{P}$ ratio of 1.65 (practically stoichiometry), and with a higher homogeneity of the fibers obtained, thus producing a better material for biomedical applications. In past research, ${ }^{47}$ it has been synthetized hydroxyapatite by the solid state method using a starfish and the $\beta$-TCP, producing a porous structure with a $\mathrm{Ca} / \mathrm{P}$ rate of 1.67 (almost stoichiometry). However, the solid state method is expensive and complicated in comparison with the one proposed here. From the previous papers ${ }^{47,49}$ and the present methodology proposed here, it is clear than the morphology depends not only on the synthesis technique, but also on the reaction times, temperatures, precursor types and concentrations.

\section{Conclusions}

In this study, the synthesis of HAp was obtained from the starfish "Mellita eduardobarrosoi sp. nov." and $\beta$-TCP using the 
hydrothermal method. The characterization of the obtained products allows to illustrate that temperature, reaction time, and concentration ratios are the most critical parameters for the synthesis of HAp. The fiber size is a function of the synthesis conditions, because as the reaction time and the temperature are increased, better defined fibers with a more homogeneous size are produced.

The results indicate that the hydrothermal method encourages the formation of HAp with specific characteristics such as dimensions that maintain high homogeneity, a suitable proportion of that phase, and a $\mathrm{Ca} / \mathrm{P}$ ratio near to stoichiometric. It is also noted that the increase in temperature and reaction time contributes to the improved the amount of HAp phase produced. This study determined that the best condition for the formation of HAp is achieved at a temperature of $250{ }^{\circ} \mathrm{C}$ using a $3: 1$ ratio of $\beta$-TCP and $\mathrm{CaO}$, with a reaction time of 48 hours, which promotes the formation of fibers with homogeneous lengths and thicknesses.

The $\mathrm{Ca} / \mathrm{P}$ ratio of HAp synthesized by the hydrothermal method was 1.65 , which is very close to the stoichiometric. From the results obtained by FTIR spectrometry, absorption bands related to the functional groups $\mathrm{PO}_{4}$ and $\mathrm{OH}$, which are characteristic of synthetic HAp were identified. Moreover, bands corresponding to the $\mathrm{PO}_{4}$ ion coming from the $\beta$-TCP precursor were also noted. Finally, a band corresponding to the $\mathrm{OH}$ bond was identified, which belongs to the $\mathrm{Ca}(\mathrm{OH})_{2}$ phase and could not be detected by XRD, likely because this phase was present in very low proportions.

Success in the production of HAp from starfish and $\beta$-TCP through hydrothermal technique suggested that it is possible to produce in a simple, cheap and reproducible method a material that can be used in diverse biotechnological applications.

\section{Acknowledgements}

The authors appreciate the technical support of Marcelo Hernández Ávila and Susana López Ortiz. Analysis were done in Laboratorio de Microscopía Electrónica de Barrido y de Difracción de Rayos $\mathrm{X}$ from Instituto Nacional de Investigaciones Nucleares. Financial funding has been provided by the projects: UNAM/DGAPA/PAPIIT IV100116, CONACyT INFR2015-251767, PROMEP - UAEH - PTC - 6669, and Laboratorio Nacional de Ciencias de la Complejidad. English language editing of this manuscript was provided by Journal Prep.

\section{References}

1 S. Tabassum, S. Zahid, F. Zarif, M. A. Gilani, F. Manzoor, F. Rehman, A. Jamal, A. A. Chaudhry, S. A. Siddiqi and I. ur Rehman, RSC Adv., 2016, 6, 104969.

2 M. González, J. A. Banderas, V. Rodríguez-Lugo and V. M. Castaño, J. Dent., 1999, 27, 595.

3 A. Bhowmick, A. Saha, N. Pramanik, S. Banerjee, M. Das and P. P. Kundu, RSC Adv., 2015, 5, 25437.

4 X. Chen, B. Yang, C. Qi, T. W. Sun, F. Chen, J. Wu, et al., Dalton Trans., 2016, 45, 1648.
5 A. A. John, A. P. Subramanian, M. V. Vellayappan, A. Balaji, S. K. Jaganathan, H. Mohandas, T. Paramalinggam, E. Supriyanto and M. Yusof, RSC Adv., 2015, 5, 39232.

6 H. S. Frederick and L. C. David, Biomaterials Science and Biocompatibillity, Springer, New York, 1996.

$7 \mathrm{~J}$. L. Lacout, in Biomaterials: hard tissue repair and replacement, ed. D. Muster, Elsevier Science Publisher, North-Holland, 1992, pp. 81-96.

8 V. Rodríguez-Lugo, G. A. Camacho-Bragado and V. M. Castaño, Mater. Manuf. Processes, 2003, 18, 67.

9 D. R. Buddy, S. H. Allan, H. J. S. Frederick and E. L. Jack, Biomaterials Science - an introduction to materials in medicine. Academic Press, New York, 1996.

10 V. S. Chandra, K. Elayaraja, K. T. Arul, S. Ferraris, S. Spriano, M. Ferraris, et al., Ceram. Int., 2015, 41, 13153.

11 H. Duan, Y. Ma, X. Liu, L. Hao and N. Zhao, RSC Adv., 2015, 5, 83522.

12 M. Manoj, D. Mangalaraj, N. Ponpandian and C. Viswanathan, RSC Adv., 2015, 5, 48705.

13 M. Sivakumar, T. Sampath-Kumar, K. L. Shantha and K. Panduranga-Rao, Biomaterials, 1996, 17, 1709.

14 V. Rodríguez-Lugo, M. Hernández and C. Angeles-Chavez, Mater. Manuf. Processes, 2003, 18, 903.

15 S. Recillas, G. Mondragón, V. Rodríguez and V. M. Castaño, Des. Monomers Polym., 2003, 6, 383.

16 M. E. Fernández, C. C. Angeles, G. Mondragón-Galicia and V. Rodríguez-Lugo, J. Mater. Sci.: Mater. Med., 2004, 15, 735.

17 V. Rodríguez-Lugo, C. Angeles-Chavez, G. Mondragon, S. Recillas-Gispert and V. M. Castaño, Mater. Res. Innovations, 2005, 9, 157.

18 V. Rodríguez-Lugo, J. Sánchez Hernández, M. J. ArellanoJiménez, P. H. Hernández-Tejeda and S. Recillas-Gispert, Microsc. Microanal., 2005, 11, 516.

19 S. Recillas, J. A. Asecencio, V. Rodríguez-Lugo and V. M. Castaño, NanoTrends, 2009, 2, 5.

20 S. Recillas, V. Rodríguez-Lugo, M. L. Montero, S. ViquezCano, L. Hernández and V. M. Castaño, J. Ceram. Process. Res., 2012, 13, 5.

21 V. Rodriguez-Lugo, D. Mendoza-Anaya and R. F. Estrada, Revista Electrónica Ideas CONCYTEG, 2012, vol. 7, p. 87.

22 E. M. Rivera-Muñoz, R. Velázquez and J. L. Cabrera, Mater. Sci. Forum, 2010, 638.

23 O. R. Bingöl and C. Durucan, Am. J. Biomed. Sci., 2012, 4, 50. 24 F. Vazquez-Hernandez, C. Mendoza-Barrera, V. Altuzar, M. Melendez-Lira, M. A. SantanaAranda and L. Olvera, Mater. Sci. Eng., B, 2010, 174, 290.

25 M. I. Kay, R. A. Young and A. S. Posner, Nature, 1964, 204, 1050. 26 M. E. Londoño, A. Echavarría and F. de la Calle, Rev. EIA, 2006, 5, 109.

27 A. Cuneyt Tas, Powder Diffr., 2001, 16, 102.

28 J. Ascencio-Gutierrez, V. Rodríguez-Lugo, C. Angeles, T. Santamaría and V. M. Castaño, Comput. Mater. Sci., 2002, 25, 413.

29 M. Yoshimura and H. Suda, J. Mater. Sci., 1994, 29, 3399.

30 M. Yoshimura and H. Suda, in Hydroxyapatite and Related Materials, ed. P. W. Brown and B. Constantz, CRC Press, Boca Raton, 1994, pp. 45-72. 
31 J. L. Cabrera, R. Velazquez-Castillo and E. M. Rivera-Muñoz, J. Nanosci. Nanotechnol., 2011, 11, 1.

32 E. M. Rivera-Muñoz, R. Huirache-Acuña, R. Velazquez, G. Alonzo-Nuñez and S. Eguía-Eguía, J. Nanosci. Nanotechnol., 2011, 1, 5592.

33 V. D. Hien, D. Q. Huong and P. T. N. Bich, J. Chem., 2010, 48, 591.

34 K. P. Sanosh, C. Min-Cheol, A. Balakrishnan, T. N. Kim and C. Seong-Jai, Bull. Mater. Sci., 2009, 32, 465.

35 R. Sang-Hoon, Biomaterials, 2002, 23, 1147.

36 K. Saranya, M. Kowshik and S. R. Ramanan, Bull. Mater. Sci., 2011, 34, 1749.

37 A. StrzaBa, W. Simka and M. MarszaBek, Acta Phys. Pol., A, 2012, 121, 561.

38 M. Sadat-Shojai, M. T. Khorasani, E. Dinpanah-Khoshdargi and A. Jamshidi, Acta Biomater., 2013, 9, 7591.

39 H. S. Liu, T. S. Chin, L. S. Lai, S. Y. Chiu, K. H. Chung, C. S. Chang and T. M. Liu, Ceram. Int., 1997, 23, 19.

40 F. Shouua and X. Ruren, Acc. Chem. Res., 2001, 34, 239.

41 A. Takeuchi, T. Tsuge and M. Kikuchi, Ceram. Int., 2016, 42, 15376.

42 C. Ma, Z. Wang, X. Lu, J. X. Lu, F. Bai, C. F. Wang, L. Li, S. X. Hou and H. D. Wang, RSC Adv., 2016, 6, 68363.

43 G. Zhu, Y. Hu, Y. Yang, R. Zhao and R. Tang, RSC Adv., 2015, 5, 23958.
44 A. Shavandi, A. E. D. A. Bekhit, A. Ali and Z. Sun, Mater. Chem. Phys., 2015, 149, 607.

45 J. Chen, Z. Wen, S. Zhong, Z. Wang, J. Wu and Q. Zhang, Mater. Des., 2015, 87, 445.

46 Y. Azis, N. Jamarun, S. Arief and H. Nur, Orient. J. Chem., 2015, 31, 1099.

47 J. Kemperl and J. Macek, Int. J. Miner. Process., 2009, 93, 84.

48 A. S. Harold and M. Telford, J. Nat. Hist., 1990, 24, 987.

49 M. I. Kay, R. A. Young and A. S. Posner, Nature, 1964, 204, 1050.

50 V. Rodríguez-Lugo, C. Angeles-Chavez and M. Hernández, Mater. Manuf. Processes, 2003, 18, 903.

51 V. Rodríguez-Lugo, G. A. Camacho and V. M. Castano, Mater. Manuf. Processes, 2003, 18, 67.

52 V. Rodríguez-Lugo, J. A. Ascencio, C. Angeles-Chavez, A. Camacho and V. M. Castano, Mater. Technol., 2001, 16, 97. 53 L. An, W. Li, Y. Xu, D. Zeng, Y. Cheng and G. Wang, Ceram. Int., 2016, 42, 3104.

54 T. J. Blokhuis, M. F. Termaat, F. C. den Boer, P. Patka, F. C. Bakker and J. T. M. Henk, J. Trauma Acute Care Surg., 2000, 48, 179.

55 K. C. Blakeslee and A. C. Tobert, J. Am. Ceram. Soc., 1971, 54, 559.

56 G. Penel, G. Leroy, C. Rey, B. Sombret, J. P. Huvenne and E. Bres, J. Mater. Sci.: Mater. Med., 1997, 8, 271. 